\title{
SPECTRAL STUDIES AND BACTERICIDAL, FUNGICIDAL, INSECTICIDAL AND PARASITOLOGICAL ACTIVITIES OF ORGANOTIN(IV) COMPLEXES OF THIO SCHIFF BASES HAVING NO DONOR ATOMS
}

\author{
Mala Nath* and Savita Goyal \\ Department of Chemistry, University of Roorkee, Roorkee 247667 (U.P.), India
}

\begin{abstract}
Twelve new organotin(IV) complexes of the type $\mathrm{R}_{\mathrm{n}} \mathrm{SnL}_{\mathrm{m}}$ [where $\mathrm{n}=3, \mathrm{~m}=1, \mathrm{R}=\mathrm{CH}_{3}$ or $\mathrm{C}_{6} \mathrm{H}_{5} ; \mathrm{n}=2, \mathrm{~m}=2, \mathrm{R}=\mathrm{C}_{6} \mathrm{H}_{5}$ or $\mathrm{C}_{4} \mathrm{H}_{9} ; \mathrm{L}=$ anion of Schiff bases derived from the condensation of 2-amino-5-(o-anisyl)-1,3,4-thiadiazole with salicylaldehyde (HL-1), 2hydroxynaphthaldehyde (HL-2) and 2-hydroxyacetophenone (HL-3)] have been synthesized and characterized by elemental analysis, molar conductances, electronic, infrared, far-infrared, ${ }^{1} \mathrm{H}$ NMR and ${ }^{119} \mathrm{Sn}$ Mössbauer spectral studies. Thermal studies of two complexes, viz., $\mathrm{Ph}_{3} \mathrm{Sn}(\mathrm{L}-\mathrm{l})$ and $\mathrm{Ph}_{2} \mathrm{Sn}(\mathrm{L}-2)_{2}$ have been carried out in the temperature range $25-1000^{\circ} \mathrm{C}$ using TG, DTG and DTA techniques. All these complexes decompose gradually with the formation of $\mathrm{SnO}_{2}$ as an end product. In vitro antimicrobial activity of the Schiff bases and their complexes has also been determined against Streptococcus faecalis, Klebsiella pneumoniae, Escherichia coli, Pseudomonas aeruginosa, Staphylococcus aureus Penicillin resistance (2500 units), Candida albicans, Cryptococcus neoformans, Sporotrichum schenckii, Trichophyton mentagrophytes and Aspergillus fumigatus. The Schiff bases (HL-1), (HL-2) and the organotin(IV) compounds have also been tested against various important herbicidal, fungicidal, insecticidal species and also for parasitological activity against freeliving nematode.
\end{abstract}

\section{INTRODUCTION}

2,5-Disubstituted-1,3,4-thiadiazole moieties have been found to possess herbicidal, radioprotective, diuretic and bacteriostatic properties (1-3). However, very little work seems to have been done on the Schiff base complexes containing heterocyclic amines. Therefore, we report herein the synthesis and characterization of organotin(IV) complexes with the Schiff bases described in Fig.1, obtained by the condensation of 2-amino-5-(o-anisyl)-1,3,4-thiadiazole with aldehydes or ketones.

\section{MATERIALS AND METHODS}

All the reagents, viz., organotin halides (Fluka), salicylaldehyde, 2-hydroxynaphthaldehyde and 2hydroxyacetophenone (Fluka) were used as received. All the chemicals and solvents used were dried and purified by standard methods, and moisture was excluded from the glass apparatus using $\mathrm{CaCl}_{2}$ drying tubes.

Carbon, hydrogen and tin content of the complexes were determined as previously reported (4). Molar conductance, electronic spectra, infrared, far-infrared, ${ }^{1} \mathrm{H}$ NMR, ${ }^{119} \mathrm{Sn}$ Mössbauer and thermal measurements were carried out on the same instruments as previously reported (5).

Antimicrobial activities of the Schiff bases and some of their organotin(IV) complexes were carried out at microbial section of the Central Drug Research Institute (CDRI), Lucknow using two fold serial dilution techniques. Herbicide, insecticide and fungicide efficacy as well as parasitological activity of a few compounds were evaluated by Cyanamid, U.S.A.

Synthesis of the Schiff bases

2-Amino-5-(o-anisyl)-1,3,4-thiadiazole was prepared by oxidative cyclisation of 2- 
methoxybenzaldehydethiosemicarbazone using ferric chloride hexa hydrate (6). The Schiff bases were prepared by refluxing 2-amino-5-(o-anisyl)-1,3,4-thiadiazole ( 1 mole) and aldehyde or ket-<smiles>[R]C([R])=Nc1nnc(-c2ccccc2OC)s1</smiles>

Where,

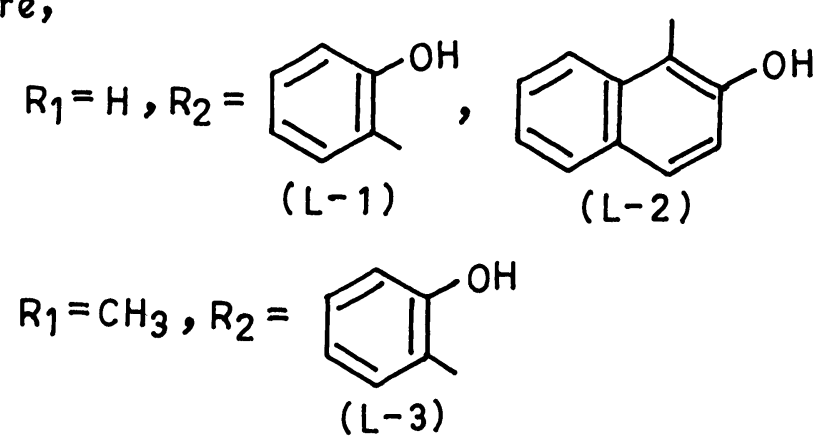

Fig. 1: General formula of the Schiff base.

tone $(1 \mathrm{~mole})$ in distilled ethanol $(50 \mathrm{ml}))$ for $2 \mathrm{hrs}$. The coloured solid was obtained on cooling after the removal of excess of solvent by distillation. It was recrystallized from the same solvent and dried under vacuum.

\section{Synthesis of the Complexes}

The complexes were prepared by the replacement reactions of tri- and diorganotin(IV) chloride with the sodium salts of the Schiff bases in 1:1 and 1:2 ratios, respectively, in absolute alcohol according to the following method.

Sodium methoxide was prepared by the dissolution of sodium $(0.16 \mathrm{~g}, 7.00 \mathrm{mmole})$ in absolute methanol $(10 \mathrm{ml})$. To this solution was added $5.00 \mathrm{mmole}$ of the Schiff base [(HL-1) to (HL-3)] in $25 \mathrm{ml}$ of methanol and the mixture was first stirred for $1 \mathrm{hr}$ and then refluxed for 2 hrs. The sodium salt of the Schiff base so obtained in solution was added dropwise to the triorganotin chloride $(5.00 \mathrm{mmole})$ or diorganotin dichloride $(2.50 \mathrm{mmole})$ in absolute methanol $(15 \mathrm{ml})$ with constant stirring. The resulting mixture was stirred for $1 \mathrm{hr}$ and then refluxed for 5-6 hrs. The contents were centrifuged to remove the sodium chloride and the unreacted sodio derivative of the Schiff base. The excess solvent was removed by distillation. The complex thus obtained was purified by recrystallization from petroleum ether $\left(60-80^{\circ} \mathrm{C}\right)$ and dried under vacuum.

$$
\mathrm{Ph}_{2} \mathrm{SnCl}_{2} / \mathrm{R}_{3} \mathrm{SnCl}+\mathrm{NaL} \stackrel{1: 2 / 1: 1}{\longrightarrow} \mathrm{Ph}_{2} \mathrm{SnL}_{2} / \mathrm{R}_{3} \mathrm{SnL}+2 \mathrm{NaCl} / \mathrm{NaCl}
$$

Where $\mathrm{R}=\mathrm{CH}_{3}$ or $\mathrm{C}_{6} \mathrm{H}_{5} ; \mathrm{L}=$ anion of Schiff bases (HL-1) to (HL-3), as indicated in Fig. 1 .

Reactions of di-n-butyltin oxide with the Schiff bases have been carried out in 1:2 molar ratio in refluxing benzene. These reactions proceed with the liberation of water, which is removed azeotropically with benzene.

$$
\mathrm{Bu}_{2} \mathrm{SnO}+2 \mathrm{HL} \underset{\text { Reflux for 8-10 hrs }}{\stackrel{\text { Benzene-methanol }}{\longrightarrow}} \mathrm{Bu}_{2} \mathrm{SnL}_{2}+\mathrm{H}_{2} \mathrm{O}
$$

Where $\mathrm{L}=$ anion of Schiff bases (HL-1) to (HL-3) 


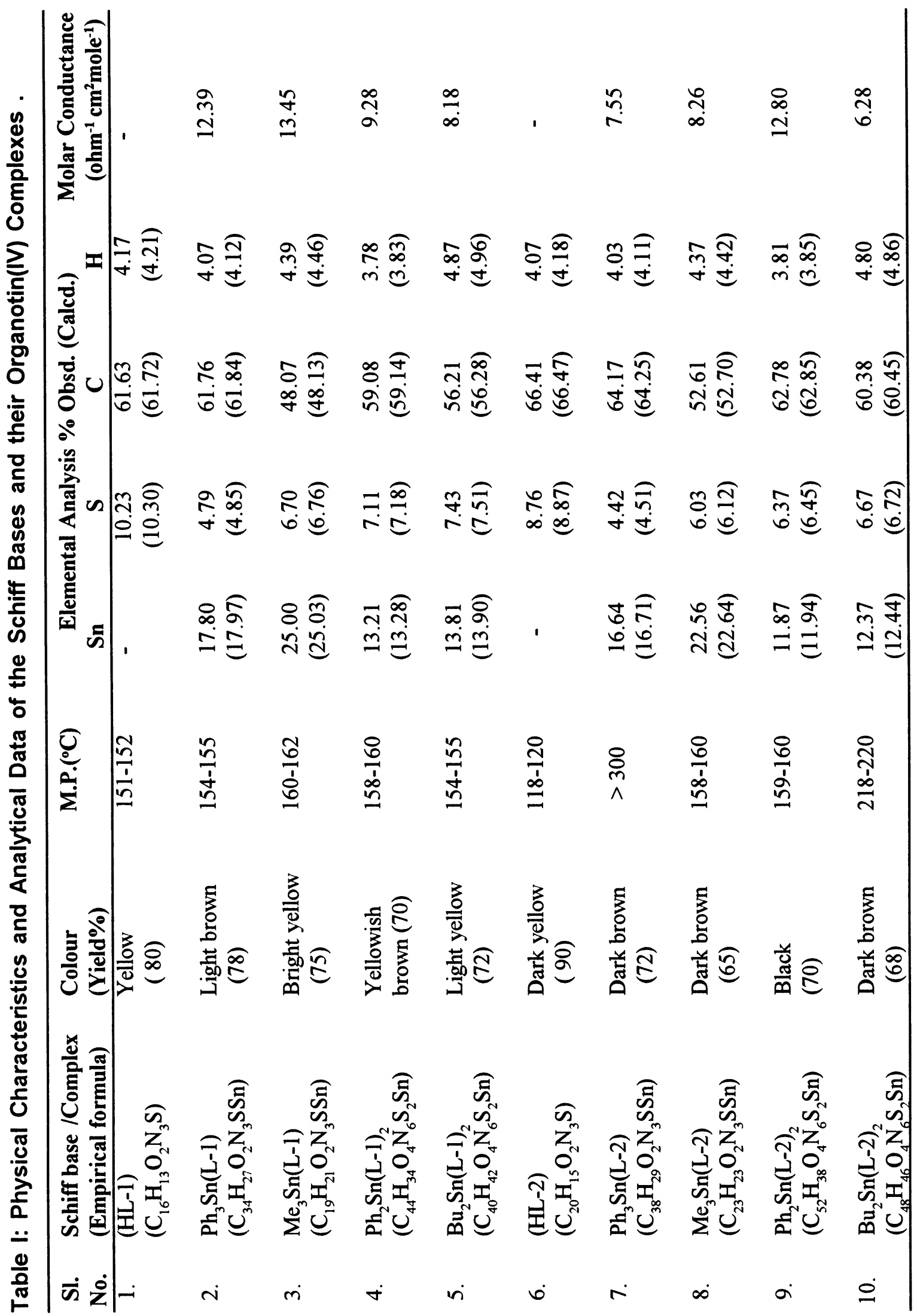




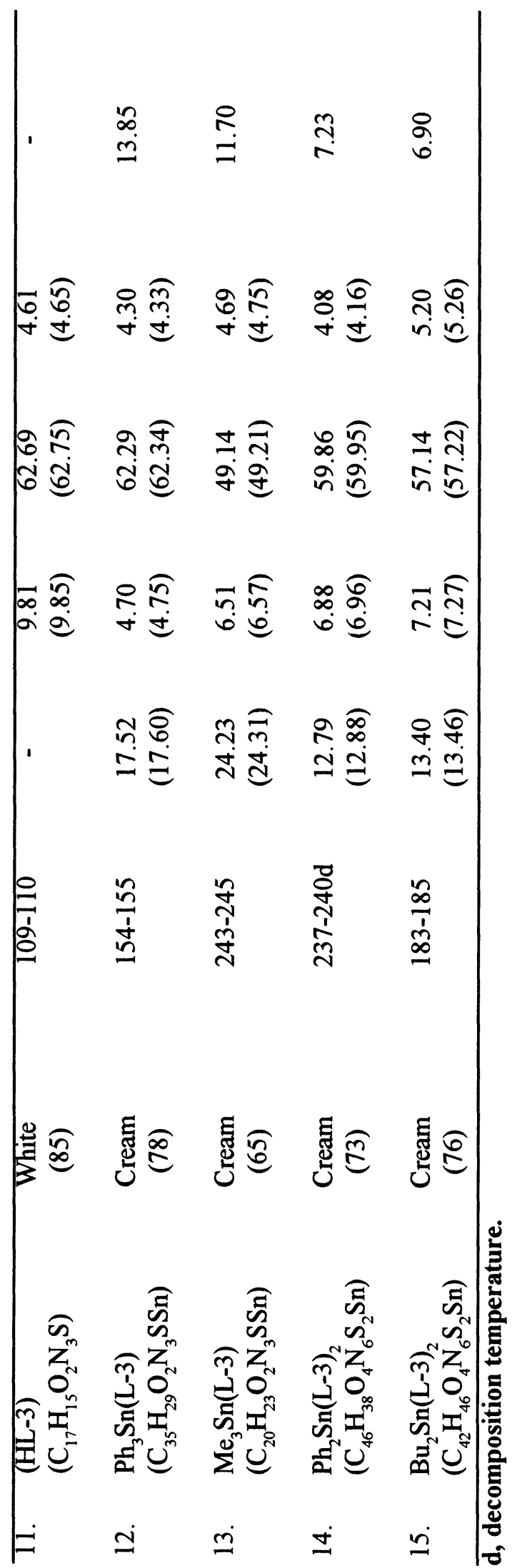


The above reactions were found to be quite facile and could be completed in 8-10 hrs of refluxing. The resulting complexes are obtained in good yield in the form of coloured solids.

\section{Results and Discussion Stoichiometry}

All the newly synthesized complexes are coloured solids and soluble in common organic solvents. The colours, yields, melting points, elemental analyses and molar conductances of the Schiff bases and their complexes are presented in Table 1. The analytical data are in good agreement with the proposed stoichiometry of the complexes. The low values of the molar conductance (6.28$13.85 \mathrm{ohm}^{-1} \mathrm{~cm}^{2} \mathrm{~mole}^{-1}$ ) are in agreement with their non-electrolytic nature.

\section{Electronic Spectra}

In the electronic spectra of the Schiff bases and of their organotin(IV) complexes, two bands are observed (Table II) in the region $217-233 \mathrm{~nm}$ and $270-309 \mathrm{~nm}$ which may be asTable II: Electronic Spectral Bands (in $\mathrm{nm}$ ) and their Assignments in the Schiff Bases and their Complexes

\begin{tabular}{llllll}
\hline $\begin{array}{l}\text { Sl. } \\
\text { No. }\end{array}$ & $\begin{array}{l}\text { Schiff base/ } \\
\text { Complex }\end{array}$ & $\begin{array}{c}\pi-\pi^{*} \\
\text { (benzenoid) }\end{array}$ & $\begin{array}{c}\pi-\pi^{*} \\
(\mathrm{C}=\mathrm{N})\end{array}$ & $\begin{array}{l}\text { Charge trans- } \\
\text { fer band from } \\
\text { ligand to tin }\end{array}$ & $\begin{array}{l}\text { Secondary band of ben- } \\
\text { zene ring coupled with } \\
\text { intramolecular charge } \\
\text { transfer band }\end{array}$ \\
\hline 1. & $(\mathrm{HL}-1)$ & 223 & 293 & - & 372 \\
2. & $\mathrm{Ph}_{3} \mathrm{Sn}(\mathrm{L}-1)$ & 221 & 293 & 322 & 372 \\
3. & $\mathrm{Me}_{3} \mathrm{Sn}(\mathrm{L}-1)$ & 227 & 280 & 318,325 & 369 \\
4. & $\mathrm{Ph}_{2} \mathrm{Sn}(\mathrm{L}-1)_{2}$ & 224 & 287 & 313,331 & 380 \\
5. & $\mathrm{Bu}_{2} \mathrm{Sn}(\mathrm{L}-1)_{2}$ & 231 & 270 & 318 & 370 \\
6. & $(\mathrm{HL}-2)$ & 219 & 309 & - & 355,428 \\
7. & $\mathrm{Ph}_{3} \mathrm{Sn}(\mathrm{L}-2)$ & 224 & $293 \mathrm{sh}$ & 319 & 538 \\
8. & $\mathrm{Me}_{3} \mathrm{Sn}(\mathrm{L}-2)$ & 233 & 272 & 319 & 538 \\
9. & $\mathrm{Ph}_{2} \mathrm{Sn}(\mathrm{L}-2)_{2}$ & 230 & 295 & 318 & 489 \\
10. & $\mathrm{Bu}_{2} \mathrm{Sn}(\mathrm{L}-2)_{2}$ & 228 & 288 & 321 & 410 sh \\
11. & $(\mathrm{HL}-3)$ & 222 & $294 \mathrm{sh}$ & - & 388 \\
12. & $\mathrm{Ph}_{3} \mathrm{Sn}(\mathrm{L}-3)$ & 217 & 290 & 328 & 397 \\
13. & $\mathrm{Me}_{3} \mathrm{Sn}(\mathrm{L}-3)$ & 233 & 293 & 325 & 388 \\
14. & $\mathrm{Ph}_{2} \mathrm{Sn}(\mathrm{L}-3)_{2}$ & 227 & 277 & 313 & 334 \\
15. & $\mathrm{Bu}_{2} \mathrm{Sn}(\mathrm{L}-3)_{2}$ & 224 & 296 & 318 & \\
\hline
\end{tabular}

sh, shoulder; $a$, in methanol.

signed to $\pi-\pi^{*}$ transition of the benzenoid and of the $>C=N$ chromophore, respectively. A band in the region $355-538 \mathrm{~nm}$ in the spectra of the Schiff bases and complexes is likely to 
be the secondary band of the benzene ring coupled with the intramolecular charge transfer transition taking place within the ligand moiety. Furthermore, sharp bands were observed in the region 313-331 nm in the spectra of the complexes which could be assigned to the charge transfer transition from ligand to tin (7).

\section{Infrared Spectra}

The characteristic infrared frequencies of the Schiff bases and their organotin(IV) complexes are given in Table III. The infrared spectra of the Schiff bases exhibit a band at $\sim 2940$ $\mathrm{cm}^{-1}$ characteristic of hydrogen bonded phenolic $\mathrm{vOH}$ vibrations (8). It is absent in the spec-

Table III: Structurally Important IR Absorption Bands $\left(\mathrm{cm}^{-1}\right)$ of the Schiff Bases and their Complexes

\begin{tabular}{|c|c|c|c|c|c|c|}
\hline $\begin{array}{l}\text { Sl.* } \\
\text { No. }\end{array}$ & $\begin{array}{c}v \mathrm{C}=\mathrm{N} \\
\text { (azomethine) }\end{array}$ & $\begin{array}{l}v>C= \\
N-N=C<\end{array}$ & $v \mathrm{C}-\mathrm{O}$ & $v \mathbf{S n} \leftarrow \mathbf{N}$ & $v S n-O$ & $v_{a s}, v_{s} S n-C$ \\
\hline 1. & $1632 \mathrm{~m}$ & $1600 \mathrm{vs}$ & $1258 \mathrm{~m}$ & - & - & - \\
\hline 2. & $1622 m$ & $1598 \mathrm{vs}$ & $1280 \mathrm{vs}$ & $412 v s$ & $530 \mathrm{vs}$ & $270 \mathrm{~s}, 235 \mathrm{~m}$ \\
\hline 3. & $1612 \mathrm{~m}$ & $1598 \mathrm{vs}$ & $1265 \mathrm{~s}$ & $426 \mathrm{~m}$ & $505 \mathrm{~m}$ & $626 \mathrm{~m}, 570 \mathrm{~m}$ \\
\hline 4. & $1617 \mathrm{~m}$ & $1598 \mathrm{vs}$ & $1273 v s$ & $424 m$ & $570 \mathrm{~m}$ & $262 \mathrm{~m}, 226 \mathrm{~m}$ \\
\hline 5. & $1620 \mathrm{~m}$ & $1598 \mathrm{vs}$ & $1268 \mathrm{vs}$ & $424 s$ & $568 v s$ & $606 \mathrm{~m}, 530 \mathrm{~m}$ \\
\hline 6. & $1628 \mathrm{~m}$ & $1596 \mathrm{vs}$ & $1256 \mathrm{~s}$ & - & - & - \\
\hline 7. & $1610 \mathrm{~m}$ & $1595 \mathrm{vs}$ & $1272 \mathrm{vs}$ & $413 v s$ & $540 s$ & $271 \mathrm{~m}, 233 \mathrm{~s}$ \\
\hline 8. & $1609 \mathrm{~m}$ & $1595 \mathrm{vs}$ & $1267 \mathrm{vs}$ & $431 \mathrm{~s}$ & $498 v s$ & $615 \mathrm{~m}, 540 \mathrm{~m}$ \\
\hline 9. & $1613 \mathrm{~m}$ & $1596 \mathrm{vs}$ & $1276 \mathrm{vs}$ & $442 v s$ & $571 \mathrm{~m}$ & $260 \mathrm{~m}, 222 \mathrm{~s}$ \\
\hline 10. & $1615 \mathrm{~m}$ & $1596 v s$ & $1272 \mathrm{~s}$ & $42 \operatorname{lvs}$ & $560 \mathrm{~s}$ & $590 \mathrm{~s}, 530 \mathrm{~m}$ \\
\hline 11. & $1630 \mathrm{~m}$ & $1602 \mathrm{vs}$ & $1250 \mathrm{vs}$ & - & - & - \\
\hline 12. & $1611 \mathrm{~m}$ & $1602 \mathrm{vs}$ & $1262 \mathrm{vs}$ & $444 m$ & $535 \mathrm{~s}$ & $268 \mathrm{~s}, 232 \mathrm{~m}$ \\
\hline 13. & $1607 \mathrm{~m}$ & $1601 \mathrm{vs}$ & $1259 \mathrm{~s}$ & $431 \mathrm{~m}$ & $505 \mathrm{~s}$ & $605 \mathrm{~s}, 560 \mathrm{vs}$ \\
\hline 14. & $1612 m$ & $1602 \mathrm{vs}$ & 127lvs & $440 \mathrm{~s}$ & $569 v s$ & $260 \mathrm{~m}, 228 \mathrm{~m}$ \\
\hline 15. & $1614 m$ & $1602 \mathrm{vs}$ & $1273 \mathrm{~m}$ & $434 \mathrm{~s}$ & $565 \mathrm{vs}$ & $595 \mathrm{~m}, 535 \mathrm{~m}$ \\
\hline
\end{tabular}

*, Sl.Nos. are those as indicated in Table I; $\mathrm{m}$, medium; vs, very strong; s, strong.

tra of the complexes suggesting the deprotonation of the phenolic $\mathrm{OH}$ group on complex formation. The appearance of azomethine $v \mathrm{C}=\mathrm{N}$ vibrations in all the Schiff bases at lower frequencies $\left(1632 \pm 2 \mathrm{~cm}^{-1}\right)$ in comparison with the normal position $\left(1675 \mathrm{~cm}^{-1}\right)$ indicates the involvement of the azomethine nitrogen atoms in hydrogen bonding (Fig. II). This band suffers a negative shift $\left(1615 \pm 8 \mathrm{~cm}^{-1}\right)$ on complex formation suggesting coordination of the azomethine nitrogen to tin. Other characteristic IR bands observed in the spectra of the Schiff bases at $1599 \pm 3,1022 \pm 2$ and $676 \pm 2 \mathrm{~cm}^{-1}$ have been assigned (9) to the $v>\mathrm{C}=\mathrm{N}-$ $\mathrm{N}=\mathrm{C}<$ (cyclic), $\mathrm{vN}-\mathrm{N}$ and $\mathrm{vC}-\mathrm{S}-\mathrm{C}$ modes of vibrations, respectively, of the thiadiazole 
ring. In the spectra of all the complexes these vibrations remain almost unchanged indicating, thereby, non-involvement of the ring nitrogen and sulphur in coordination. The IR spectra of the Schiff bases display a band at $1254 \pm 4 \mathrm{~cm}^{-1}$, characteristic of the phenolic $\mathrm{VC}-\mathrm{O}$ vibration undergoes a positive shift in the spectra of the complexes indicating coordination<smiles>COc1ccccc1-c1nnc2[nH]c3ncc4ccccc4oc=3nc-2s1</smiles>

(I)<smiles>COc1ccccc1-c1nnc(N2[CH]Oc3ccccc3C2)s1</smiles>

(II)

Fig. II: Hydrogen bonded structure of (LH-1).

of the Schiff bases through the phenolic oxygen atom. The coordination through the oxygen and nitrogen is further supported by the occurrence of new bands at $535 \pm 37$ and $428 \pm 16 \mathrm{~cm}^{-1}$ in the spectra of the complexes which may be assigned (10) to $v \mathrm{Sn}-\mathrm{O}$ and $v \mathrm{Sn} \leftarrow \mathrm{N}$, respectively. The far-IR spectra of $\mathrm{Ph}_{3} \mathrm{SnL}$ and $\mathrm{Ph}_{2} \mathrm{SnL}_{2}$ show bands at $265 \pm 6$ and $229 \pm 7 \mathrm{~cm}^{-1}$ which may be assigned $(7,11)$ to the $v_{\mathrm{as}} \mathrm{Sn}-\mathrm{C}$ and $v_{\mathrm{s}} \mathrm{Sn}-\mathrm{C}$, respectively, whereas the corresponding bands at $608 \pm 18$ and $550 \pm 20 \mathrm{~cm}^{-1}$ have also been assigned (10) in the spectra of $\mathrm{Me}_{3} \mathrm{SnL}$ and $\mathrm{Bu}_{2} \mathrm{SnL}_{2}$.

\section{${ }^{1}$ H NMR Spectra}

The conclusion drawn from ${ }^{1} \mathrm{H}$ NMR spectral studies lend further support to the mode of bonding discussed above. The ${ }^{1} \mathrm{H}$ chemical shifts $\delta$ (in ppm) of the Schiff bases and their complexes are listed in Table IV. A signal at $8.50 \pm 0.20 \mathrm{ppm}$ due to the intramolecularly hydrogen bonded phenolic proton $(8,9)$ of the Schiff bases disappear in the ${ }^{1} \mathrm{H}$ NMR spectra of the organotin complexes indicating, thereby, the substitution of the phenolic proton by the organotin moiety. The signals due to the azomethine $(-\mathrm{C}(\mathrm{H})=\mathrm{N}-)$ and methyl $\left(-\mathrm{C}\left(\mathrm{CH}_{3}\right)=\mathrm{N}-\right)$ protons in the Schiff bases appear as a singlet at 7.05 and $1.60 \mathrm{ppm}$, respectively indicating that the azomethine nitrogen is hydrogen bonded $(8,9)$. In the complexes, the signals shift downfield $(2.10 \mathrm{ppm}$ for the methyl and $8.20-8.50 \mathrm{ppm}$ for the methine protons) as compared to their positions in the free Schiff bases owing to the coordination of the azomethine nitrogen to tin $(8,9)$. The signals at $4.57 \pm 0.03 \mathrm{ppm}$ in the Schiff bases has been assigned to the $-\mathrm{OCH}_{3}$ protons which remains unaltered on complexation and thus clearly indicates the non-involvement of this group in complex formation. The complex pattern observed in the region 7.00-8.25 ppm in all the complexes is due to overlapping resonances of the phenyl groups bonded to tin and of the aromatic ligand protons. The butyl protons attached to the tin appear as a complex pattern $(1.70-0.83 \mathrm{ppm})$ $(12,13)$. The number of protons of various groups calculated from the integration curves and those calculated for the expected molecular formula agrees with each other.

\section{${ }^{119}$ Sn Mössbauer Spectra and Structure Determination}

Q.S. (Quadrupole Splitting) and I.S. (Isomeric Shift) values of the complexes are presented in Table V. The complexes viz., $\mathrm{R}_{3} \mathrm{SnL}\left(\mathrm{R}=\mathrm{CH}_{3}\right.$ or $\left.\mathrm{C}_{6} \mathrm{H}_{5}\right)$ and $\mathrm{R}_{2} \mathrm{SnL}_{2}\left(\mathrm{R}=\mathrm{C}_{6} \mathrm{H}_{5}\right.$ or $\left.\mathrm{C}_{4} \mathrm{H}_{9}\right)$ are five- and six-coordinated, respectively, having monofunctional bidentate ligands with $\mathrm{ON}$ donor sites as indicated from the IR data. Trigonal bipyramidal $\mathrm{R}_{3} \mathrm{SnL}(\mathrm{L}=$ bidentate ligand $)$ complexes have been reported $(11,14)$ to have different Q.S. for the following three isomers (Q.S. 1.7-2.3 $\mathrm{mm} \mathrm{s}^{-1}$ for $\mathrm{a} ; 3.0-3.9 \mathrm{~mm} \mathrm{~s}^{-1}$ for $\mathrm{b}$ and 3.5-4.1 $\mathrm{mm} \mathrm{s}^{-1}$ for $\mathrm{c}$ in Fig. III). The observed values of 


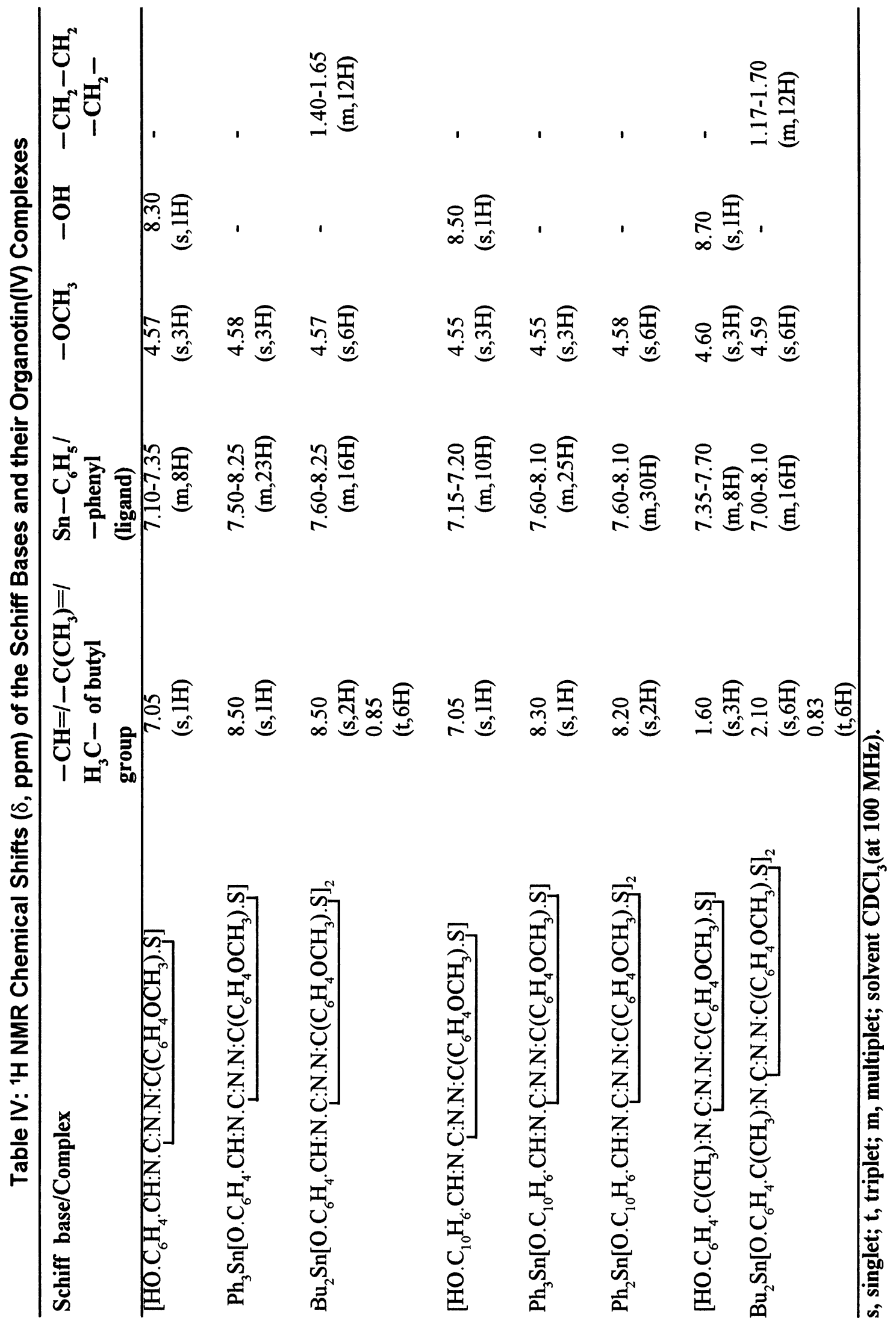


Q.S. (Table V) of the complexes, viz., $\mathrm{Ph}_{3} \mathrm{Sn}(\mathrm{L}-2), \mathrm{Ph}_{3} \mathrm{Sn}(\mathrm{L}-3)$, and $\mathrm{Me}_{3} \mathrm{Sn}(\mathrm{L}-3)$ suggest the structure (a).

From the observed Q.S. (1.91-2.56 $\mathrm{mm} \mathrm{s}^{-1}$ ) for the complexes, $\mathrm{R}_{2} \mathrm{SnL}_{2}\left[\mathrm{R}=\mathrm{C}_{6} \mathrm{H}_{5}\right.$ or $\mathrm{C}_{4} \mathrm{H}_{9}$ ; $\mathrm{L}=$ anion of (HL-1) to (HL-3)], the existence of cis- $\mathrm{R}_{2} \mathrm{Sn}(\mathrm{IV})$ moieties in a distorted octahe-

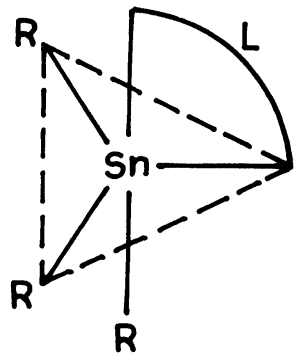

(a)

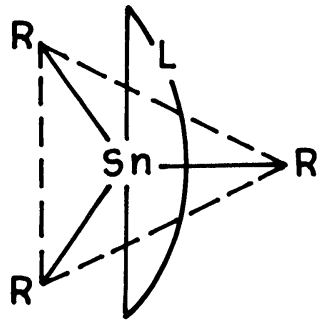

(b)

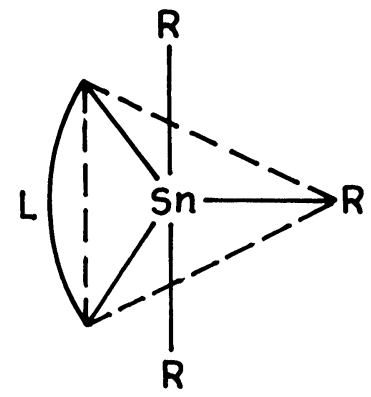

(c)

Fig. III: Possible isomers of trigonal bipyramidal $\mathrm{R}_{3} \operatorname{SnL}(\mathrm{L}=$ bidentate ligand)

dral arrangement around tin atom (Fig. IV) has been suggested which is also consistent with the IR data.

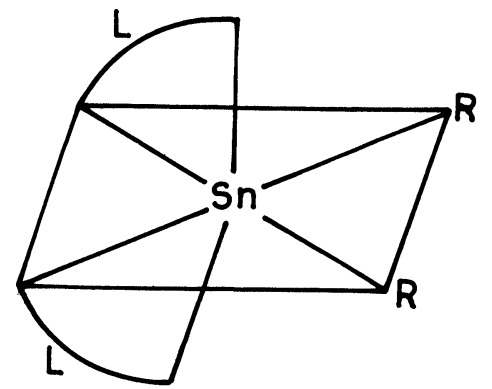

Fig IV : Structure of $\mathrm{R}_{2} \mathrm{SnL}_{2}\left[\mathrm{R}=\mathrm{C}_{6} \mathrm{H}_{5}\right.$ or $\mathrm{C}_{4} \mathrm{H}_{9} ; \mathrm{L}=$ anion of (HL-1) to (HL-3)].

Table V: The ${ }^{119} \mathrm{Sn}$ Mössbauer Spectroscopic Data of Organotin(IV) Complexes

\begin{tabular}{lll}
\hline Complex & Q.S. $\left(\mathbf{m m ~ s}^{-1}\right)$ & I.S. $\left(\mathbf{m m ~ s}^{-1}\right)$ \\
\hline $\mathrm{Ph}_{2} \mathrm{Sn}(\mathrm{L}-1)_{2}$ & $1.91 \pm 0.05$ & $0.97 \pm 0.01$ \\
$\mathrm{Ph}_{3} \mathrm{Sn}(\mathrm{L}-2)$ & $2.44 \pm 0.06$ & $1.10 \pm 0.01$ \\
$\mathrm{Ph}_{2} \mathrm{Sn}(\mathrm{L}-2)_{2}$ & $2.15 \pm 0.07$ & $1.12 \pm 0.27$ \\
$\mathrm{Ph}_{3} \mathrm{Sn}(\mathrm{L}-3)$ & $2.19 \pm 0.05$ & $1.16 \pm 0.01$ \\
$\mathrm{Me}_{3} \mathrm{Sn}(\mathrm{L}-3)$ & $2.82 \pm 0.04$ & $1.15 \pm 0.01$ \\
$\mathrm{Ph}_{2} \mathrm{Sn}(\mathrm{L}-3)_{2}$ & $2.56 \pm 0.04$ & $1.27 \pm 0.01$ \\
$\mathrm{Bu}_{2} \mathrm{Sn}(\mathrm{L}-3)_{2}$ & $2.09 \pm 0.05$ & $0.99 \pm 0.01$ \\
\hline
\end{tabular}

\section{Antimicrobial Activity}

The antimicrobial activity data, compiled in Table VI, show that all the Schiff bases are active against fungal strains 6 to 10 only. Among all the Schiff bases, (HL-2) was found to be the 


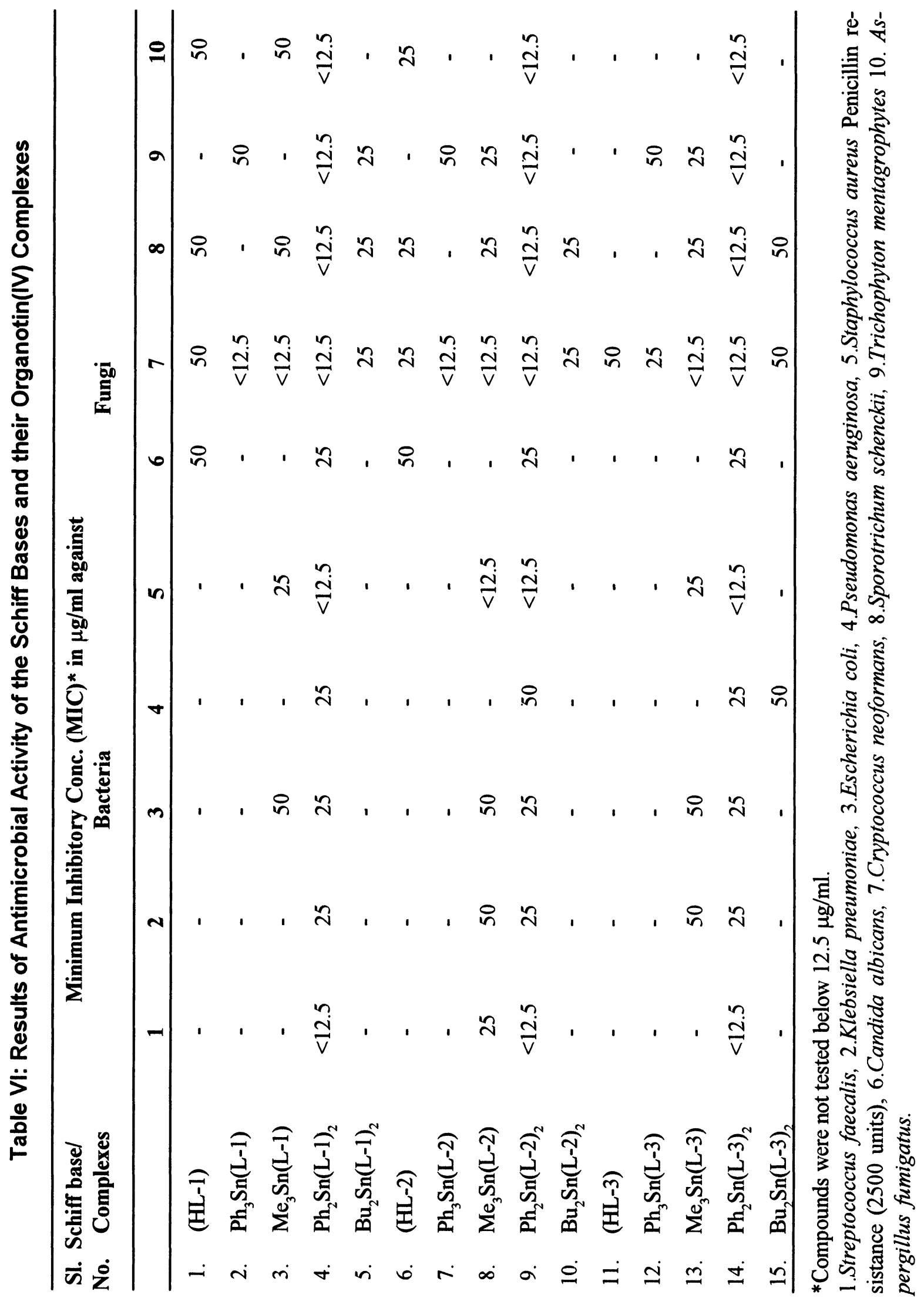


most active. The Schiff bases (HL-1) and (HL-2) were found to be active against fungal strains $6,7,8$ and 10, and (HL-3) was active against fungal strain 7 only.

As evident from Table VI, diphenyltin complexes are very active against all the bacteria and fungi used and show lower MIC values in comparison to the Schiff bases. The other complexes also show greater bactericidal and fungicidal activities as compared to their corresponding Schiff bases and show lower MIC values than those of the Schiff bases. The order of the activity is as follows: $\mathrm{Ph}_{2} \mathrm{SnL}_{2}>\mathrm{Me}_{3} \mathrm{SnL}>\mathrm{Ph}_{3} \mathrm{SnL}>\mathrm{Bu}_{2} \mathrm{SnL}_{2}$.

Thus the results clearly indicate that the organotin(IV) complexes possess moderate bactericidal and fungicidal activities. The results of herbicidal, insecticidal, fungicidal and parasitological activities of (HL-1) and (HL-2), and the organotin complexes derived from them (see Table VII) indicate that all the compounds tested except $\mathrm{Ph}_{3} \mathrm{Sn}(\mathrm{L}-2)$ are completely inactive against the various species mentioned.

Table VII: Results of Biological Activities of the Schiff Bases and their Complexes

\begin{tabular}{|c|c|c|c|c|c|c|}
\hline \multirow{2}{*}{$\begin{array}{l}\text { Schiff base/ } \\
\text { complex }\end{array}$} & \multicolumn{2}{|c|}{ Herbicide } & \multirow{2}{*}{$\begin{array}{l}\text { Insecticide } \\
\text { Primary }\end{array}$} & \multicolumn{2}{|c|}{ Fungicide } & \multirow{2}{*}{$\begin{array}{l}\text { Animal Health } \\
\text { Nematode }\end{array}$} \\
\hline & Mini & High & & Mini & Primary & \\
\hline (HL-1) & $\varphi$ & - & $\varphi$ & $\varphi$ & - & $\varphi$ \\
\hline $\mathrm{Ph}_{3} \mathrm{Sn}(\mathrm{L}-1)$ & $\varphi$ & - & $\varphi$ & $\varphi$ & - & $\varphi$ \\
\hline $\mathrm{Bu}_{2} \mathrm{Sn}(\mathrm{L}-1)_{2}$ & $\varphi$ & - & $\varphi$ & $\varphi$ & - & $\varphi$ \\
\hline (HL-2) & $\varphi$ & - & $\varphi$ & $\varphi$ & - & $\varphi$ \\
\hline $\mathrm{Ph}_{3} \mathrm{Sn}(\mathrm{L}-2)$ & $\varphi$ & - & $\varphi$ & 5 & $\varphi$ & $\varphi$ \\
\hline $\mathrm{Me}_{3} \mathrm{Sn}(\mathrm{L}-2)$ & $\varphi$ & - & $\varphi$ & $\varphi$ & - & $\varphi$ \\
\hline $\mathrm{Bu}_{2} \mathrm{Sn}(\mathrm{L}-2)_{2}$ & $\varphi$ & - & $\varphi$ & $\varphi$ & - & $\varphi$ \\
\hline
\end{tabular}

$\varphi$, Compound inactive; 5 , Compound has some activity;

Herbicidal Species- Abutilon theophrasti, Alopecurus myosuroides, Ambrosia artemisiifolia, Avena fatua, Brassica kaber, Bromus tectorum, Cyperus rotundus, Echinochola crus-galli, Elytrigia repens, Galium aparine, Glycine max, Ipomoea spp., Lolium multiflorum, Sesbania exaltata, Setaria viridis, Sorghum halepense, Triticum aestivum, Zea mays

Insecticidal Species- Spodoptera eridania, Tetranychus urticae, Diabrotica undecimpunctata

Fungicidal Species (Mini screen)- Botrytis cinerea, Sphaerotheca fuliginea, Pseudoperonospora cubensis, Rhizoctonia solani

Fungicidal Species (Primary screen) In vivo- Venturia inaequalis, Plasmopara viticola, Botrytis cineria, Pyricularia oryzae, Cercospora beticola, Phytophthora infestans, Puccinia recondita, Puccinia gramminis

In vitro- Fusarium oxysporum, Pythium ultimum, Rhizoctonia solan, Pseudocercosporella sp.

Thermal Studies

Thermal decomposition of two complexes, viz., $\mathrm{Ph}_{3} \mathrm{Sn}(\mathrm{L}-1)$ and $\mathrm{Ph}_{2} \mathrm{Sn}(\mathrm{L}-2)_{2}$ has been studied using TG, DTG and DTA techniques. Both complexes decompose gradually with the formation of $\mathrm{SnO}_{2}$ as an end product. 


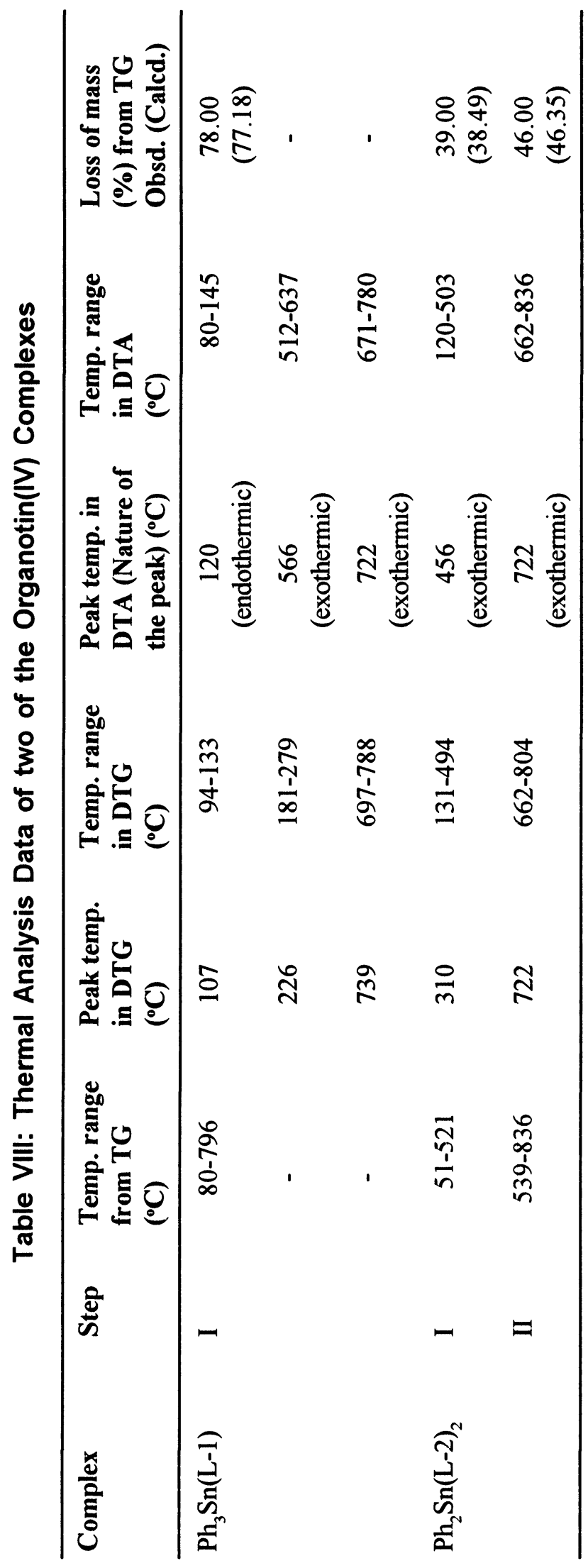


As evident from Table VIII no sharp and distinct plateau was observed for the loss of the ligand or organic groups attached to tin in the $\mathrm{TG}$ curve of $\mathrm{Ph}_{3} \mathrm{Sn}(\mathrm{L}-1)$ in the temperature range $80-796^{\circ} \mathrm{C}$ whereas DTA and DTG show three peaks at 120 (endothermic), 566, $722^{\circ} \mathrm{C}$ (both exothermic) and $107,226,739^{\circ} \mathrm{C}$, respectively. The total observed weight loss in TG $(78.00 \%)$ corresponds to the formation of $\mathrm{SnO}_{2}$ as end product of the decomposition of the complex. The observed ' $d$ ' values in the residue were 3.36, 2.58, 1.77 and 2.30 and Obsd: Sn was $78.69 \%$ whereas the reported ' $d$ ' values in $\mathrm{SnO}_{2}$ are 3.35, 2.64, 1.77, 2.37 (15).

As evident from Table VIII the first step of the decomposition of the complex $\mathrm{Ph}_{2} \mathrm{Sn}(\mathrm{L}-2)_{2}$ extends from 51 to $521{ }^{\circ} \mathrm{C}$ and the observed weight loss (39.00\%) as against the calculated value $(38.49 \%)$ corresponds to the loss of the thiadiazole moiety of the ligand $(2$ mole) giving $\mathrm{C}_{34} \mathrm{H}_{24} \mathrm{~N}_{2} \mathrm{O}_{2} \mathrm{Sn}$ as intermediate (I) which is supported by elemental analyses (Obsd: $\mathrm{C}, 66.72 ; \mathrm{H}$, 3.87; Sn, 19.36\%; Calcd: C, 66.81; H, 3.96; Sn, $19.42 \%$ for $\mathrm{C}_{34} \mathrm{H}_{24} \mathrm{~N}_{2} \mathrm{O}_{2} \mathrm{Sn}$ ). It is also confirmed by the disappearance of the characteristic frequencies of the thiadiazole ring in the infrared spectrum of the residue obtained by isothermal heating of the complex at $525 \pm 4^{\circ} \mathrm{C}$. The second step of the decomposition corresponds to the loss of the organic groups attached to $\mathrm{Sn}$ and of the ligand molecules giving $\mathrm{SnO}_{2}$ as end product, which was characterized by powder $\mathrm{X}$-ray diffraction analyses and tin determination ['d' values Obsd: 3.33, 2.63, 1.79 and 2.33; Obsd: Sn, 78.78\%].

\section{REFERENCES}

1. D. R. Williams, Chem. Rev., 72, 203 (1972).

2. R. S. Srivastava, L. D. S. Yadav, R. K. Khare and A. K. Srivastava, Ind. J. Chem., 20A, 516 (1981) (References therein).

3. V. H. Shah, H. H. Patel and A. R. Parikh, J. Ind. Chem. Soc., 59, 678 (1982).

4. M. Nath and S. Goyal, Main Group Met. Chem., 16, 167 (1993).

5. M. Nath and S. Goyal, Main Group Met. Chem., 18, 51 (1995).

6. V. Ranga Rao and V. R. Srinivasan, Ind. J. Chem., 8, 59 (1970).

7. M. Nath, N. Sharma and C. L. Sharma, Synth. React. Inorg. Met. -Org. Chem., 20, 623 (1990).

8. K. C. Satpathy, B. B. Jal and R. Mishra, Ind. J. Chem., 25A, 196 (1986).

9. K. C. Satpathy, B. B. Jal and R. Mishra, Ind. J. Chem., 24A, 147 (1985).

10. R. C. Poller, Logos Press, London, (1970) (References therein).

11. L. E. Khoo, J. P. Charland, E. J. Gabe and F. E. Smith, Inorg. Chim. Acta., 128, 139 (1987).

12. R. Tiwari, G. Srivastava, R. C. Mehrotra and A. J. Crowe, Inorg. Chim. Acta, 111, 167 (1986).

13. A. Saxena and J. P. Tandon, Polyhedron., 3, 681 (1984).

14. G. M. Bancroft, B. W. Davies, N. C. Payne and T. K. Sham, J. Chem. Soc. Dalton, 973 (1975).

15. "Power diffraction file sets $1-10$, joint committe on powder diffraction standards", Philadelphia, PA, P. 21 and 1-984 (1987).

Received: September 13, 1995 - Accepted: October 2, 1995 Received in revised camera-format: November 9, 1995 